\title{
The Significance of CSF Among Enterprises in Latvia: An In-depth Analysis
}

\author{
Aleksandrs Judins \\ The Manchester Metropolitan University, Manchester, England \\ SIA Esmeralda Immobilien, Riga, Latvia \\ Irina Kuzmina-Merlino \\ University of Latvia, Riga, Latvia \\ Transport and Telecommunication Institute, Riga, Latvia
}

The present research paper is dedicated to the in-depth analysis of the significance of critical-to-success factors (CSF) among enterprises in Latvia. The goal is to distinguish and find key success factors of Latvian companies who survived the economic crisis, which started in 2008, and executed the enabling objectives of the paper. Research methodology involves the analysis of the existing theoretical literature, in-depth interviews with the top management representatives of large Latvian business entities were interviewed by GFK (Custom Research Baltic agency) on behalf of the authors of the paper. It is found out that 10 largest industries for the big companies are: fuel retail and wholesale, energetics, food retail and wholesale, chemical products, logistics, metal processing, financial services, information technologies service and production, passenger transportation, and telecommunication services. For medium companies such industries are: food retail and wholesale, logistics, fuel retail and wholesale, wood processing, automotive industry, construction, financial services, pharmaceutical products, metal processing, and beverage wholesale and production. The authors also scrutinised 72 articles of 38 Forbes magazine archiving from the years 2010-2014. Thirty CSF were defined. The most significant CSF according to the Forbes interviews are specific market niche, export, technological innovations, and high quality of products and services. The in-depth interviews with the top management representatives prove the importance of the above mentioned factors. Relevant recommendations are provided in the end of the paper.

Keywords: critical-to-success factors (CSF), key success factors, investing in Latvian economy, market niche preference, export, interviews

\section{Introduction}

Prior to starting a new business, entrepreneurs are performing market research and choosing a specific industry to operate in. Establishing a new company in a foreign country is especially complicated, as usually an

Aleksandrs Judins, MBA, Business and Law Faculty, Master of Business Administration Programme, The Manchester Metropolitan University; Managing Director at SIA Esmeralda Immobilien.

Irina Kuzmina-Merlino, Professor, Ph.D. in Economics, University of Latvia; Professor at Transport and Telecommunication Institute.

Correspondence concerning this article should be addressed to Aleksandrs Judins, Kokneses prosp. 4/1-3, Riga, Latvia, LV-1014. E-mail: a.judins@ mail.ru. 
entrepreneur is not acquainted with its economic situation and many other peculiarities. Detailed market research demands much time and effort. However, there are critical-to-success factors, which can significantly help a company to achieve great success and profit, as well as survive harsh economic situations or even deep crises. CSF vary depending on the company, economic environment, country, location, etc.. Knowing these factors for a specific industry may help an entrepreneur with conducting market research.

The significance of the present research is that it may help potential investors who are planning to start businesses or invest in the Latvian economy, to choose the most profitable industry. Defined CSF (and confirmed by Latvian enterprises) may assist and benefit them in conducting business in the Republic of Latvia.

The problem of the research is in defining and analysing CSF among enterprises in Latvia that survived the economic crisis in 2008, which already leads to a conclusion that these factors played a significant role during the fight against stagnation. Therefore, the compliance with CSF may also lead to success. The research covers and scrutinises such topics as the top industries according to turnover in Latvia, target sectors for potential investments in the country, historical background and specification of the CSF in terms of Latvian business enterprises, Latvian national economy, successful entrepreneurs in Latvia, and European Funds in Latvia, etc..

The subject of the paper is CSF applied by companies in Latvia and the data, acquired by performing the analysis of information, relevant to the current topic of the research.

The object of the paper is the TOP-500 Latvian enterprises according to their turnover in 2012, the list of the TOP-100 wealthiest people in Latvia according to their assets, 38 Forbes magazine archives from 2010-2014 and six in-depth interviews with the top managers of large Latvian business entities conducted by GFK (Custom Research Baltic agency) on behalf of the authors.

Prior research, the authors put forward seven hypotheses regarding the topic:

(1) Export activity is the main success factor of enterprises in Latvia.

(2) Government funding is one of the CSF of companies in Latvia.

(3) There are several CSF that underlie performance of enterprises in Latvia.

(4) Both large and medium companies have specific business sectors with the highest turnover levels that coincide.

(5) Market niche is one of CSF especially important for SME.

(6) EU funds are CSF of great significance for Latvian companies.

(7) There are several CSF that both large and SME define as of great and vital importance.

With a view to prove or disprove the above mentioned hypotheses, the goal of the paper is to distinguish and find key success factors of Latvian companies who survived the economic crisis, which started in 2008, and execute the enabling objectives of the paper.

In order to achieve the aforementioned goals and prove the hypotheses of the research, the following enabling objectives have been put forward:

(1) To study existing theoretical literature dedicated to CSF;

(2) To study the scientific approach of CSF implemented by multiple researchers and interaction of these factors with the practical business environment;

(3) To provide a brief look into the Latvian national economy since the beginning of the 20th century;

(4) To scrutinise top industries, in which the TOP 500 enterprises in Latvia are operating;

(5) To divide the above mentioned companies into large and medium companies; 
(6) To summarise the acquired data on the TOP 500 enterprises in Latvia;

(7) To analyse Forbes archives from 2010-2014 totalling 38 magazines;

(8) To select articles relevant to the present topic of the paper;

(9) To analyse all the interviews and define CSF;

(10) To analyse six in-depth interviews with the top managers of Latvian enterprises;

(11) To scrutinise information about high-net-worth individuals (HNWI) in order to demonstrate the industries in which the wealthiest people in Latvia are operating in;

(12) To find and analyse information about EU funds in Latvia.

(13) To draw relevant conclusions and provide recommendations to potential investors.

The research methodology involves the analysis of existing theoretical literature, interviews with either proprietary or top management of the scrutinised enterprises, and comparative research method when working with the received data. The methodology also involves private interviews with the top managers of large Latvian enterprises, which were conducted in cooperation with the international research agency GFK.

The results of the present paper may help potential investors, who are planning to start a business or invest in the Latvian economy, to choose the most profitable industry. Defined CSF may assist and benefit them in conducting business in Latvia.

\section{Brief Look Into Latvian National Economy Since the Beginning of the 20th Century}

From the 20th century until the present day, the Latvian economy can be divided into four major sections: Latvia in the time of the Russian Empire, the period following World War I; the independency period of the Republic of Latvia; World War II and the subsequent incorporation of Latvia into the USSR; and the restoration of independence of the Republic of Latvia and subsequent EU accession.

The industrial production revolution that had begun in Latvia in the 1830s, continued through to the second half of the 19th century. Factories replaced manufacturing. By 1847, 14 companies in Riga were already using steam engines and boilers, although manual work was still applied. In the 1840s, two steam engines were operating in Strazdumuiza textile; and in 1848-1849, the first machine was set up in a paper-making company in Ligatne. At the same time, the concentration of labour and production at large companies was taking place (in 1894, in nine enterprises there were more than 200 employees; $41.3 \%$ of industrial output was produced). Riga was the main industrial centre in Latvia (in 1834, there were 33 factories (1,593 employees), in 1860, there were 1,889 factories (6,134 employees)). Textile was the leading industry, in which eight enterprises were operating. The largest were Pihlavas kokvilnas fabrika (782 employees), Sepera kokvilnas fabrika (500 employees), and Tilo fabrika (Zasulauka manufaktura, (420 employees)). Second place was held by the tobacco industry. Prior to the construction of the railway, the main market outlet was the Baltics, however, after its opening goods produced in Riga were transferred to Poland, Belarus, and the Russian hinterland. In other Baltic governorates, the production sector was less developed. In Kurzeme (a region of Latvia) - in Liepaja and Ventspils cities, there were working shipyards; in 1840, in Liepaja a bone flour factory started to operate (it was closed in 1847, with an ironwork factory opening later in its place). During 10 years (1848-1857), Liepajas kugu buvetava shipyard built 48 ships. Factories also started to appear in rural manors. The main product was vodka (in the Latvian region Vidzeme, the vodka production rate was $10 \%$, in Kurzeme- $50 \%$ of production). 
The end of the century faced crisis, but after overcoming this, the Baltic industrial sector saw a rapid development of companies that were co-owned by representatives of various countries. In 1890, Latvian industries were employing approximately 25.5 thousand persons (in Vidzeme-18.8 thousand, in Kurzeme -4.9 thousand, and in Latgale -1.8 thousand). The main industries were wood processing, metal processing and mechanical engineering, chemical industry, and food industry. At the end of the century, Latvian ports were significant in exporting and importing not only local production, but also all goods of the Russian Empire (Tilde, 1998-2012).

At the beginning of the 20th century, Latvia became one of the most developed governorates of the Russian empire. It was an important industrial and agrarian region, as well as the financial centre of the Baltics, with its developed banking sector. Rapid development of industry contributed to changes in the social structure of the population. There was a significant increase in the number of employees; the ethnic composition of workers living in cities, was rather diverse. However, the majority of employees, residing in rural areas, were Latvians, many of whom were still subjected to servitude and were often only employed as slave labour, in the manufactories of their owners. Huge areas of land belonged to landlords affecting landless peasants, the number of which exceeded 50\%. Unable to provide for themselves, peasants were forced to become wage-earning agricultural workers or face moving to a city, which only a few managed to do. Capital was mainly concentrated in German (Kurzeme and Vidzeme) and Polish (Latgale) manors, as well as in the hands of Russian officials (Riga region). Sharp social, ethnical, and political conflicts became the reason for the Revolution of 1905 and the following military confrontation (Tukums uprising, Aizputes war, etc.).

In the beginning of the 20th century, the above mentioned industry sectors preserved their leadership. However, the economic crisis of 1900 to 1903 dramatically affected them. Nevertheless, starting in 1909, industrial production gained new momentum, and by the year 1913, industrial enterprises and their employees doubled in number. This economic breakthrough also had a significant effect on banks.

The Russian-Baltic wagon factory (in 1908-1914, its production volume increased 2.9 times) became a universal mechanical engineering enterprise that started producing cars (in 1908 it produced 170 cars and lorries), agricultural machinery and aircraft (in 1915, this factory produced and tested the first tracked military vehicle in the world). Wagon factory "Fenikss" was also modernised. Shipbuilding and machine factory "Lange un dels" was producing river boats and barges. General electric company plants (the largest was "Unions" factory) significantly increased the variety of electrical products available. At that time, the largest Latvian enterprise "Provodniks" which produced rubber, gutta-percha, and linoleum products employed 14 thousand people. This was one of the four largest rubber companies in the world and the second largest enterprise that produced tires for aircraft, cars, and bicycles. Latvian industries suffered severely during the WWI due to their evacuation. A large proportion of production equipment was permanently lost.

In the newly established Republic of Latvia, industries needed to be recreated and the new situation dictated new rules. There was a need for other kinds of goods, therefore, food and light industries began to develop, whose production in the first years mainly went to the local market (approximately 80\%). Metal processing and chemical industries, which played an important role in the pre-war period, were not restored to previous levels, as this required major investment. For local consumption and export, there was a rapid growth in production in forestry, wood processing and paper manufacturing industries. In 1923, Latvia took first place in this sphere; it employed approximately $20 \%$ of all workers. Latvia was exporting paper, plywood, matches, rubber, and other products. During 1920-1929, the value of manufactured products grew approximately fourfold. This successful 
development period was interrupted by the world economic crisis that began in the late twenties and early thirties, affecting Latvia as well- there was a decline in production and some enterprises were closed.

Electro technical factory (VEF, founded in 1919) became the biggest company in the Baltics in the present sector. It produced telephones (4.8 thousand pieces in 1938), radios (32 thousand pieces in 1938), telephone exchanges, aircraft plywood, electricity meters, irons and vacuum cleaners, and since $1937 \mathrm{VEF}$, started to manufacture the world's smallest camera "Minox" that achieved international recognition. During the World War II, this product (including the technical and patent documentation) was taken as war booty by Germany and continued to be produced in West Germany. In the late 1930s, VEF began to produce light aircraft (constructor K.Irbitis). This production (and technical documentation) after 17 of June 1940 was taken into USSR (Aizsilnieks, 1968).

Before 1940, there were many successful companies belonging to both local and foreign entrepreneurs. During this period, the agricultural sector was especially successful in developing. At the beginning of the 20th century, the Latvia agricultural industry was the most developed in the whole of inner Russia - arable land was used more intensively, therefore, the volumes of harvest rose higher. Milk production for both landlords and farms achieved a good level for those times (with a single cow producing, on average, two thousand litres of milk per year). There was a good outlet for pedigree cattle and butter on the all-Russian market. Most of the land was still owned by landlords. Out of 5,409.6 thousand dessiatin of arable land, 48.3\% was privately owned (mostly by landlords), $38.5 \%$ was owned by peasants, approximately $11 \%$ by the government and less than $2 \%$ by vicarages, urban estates, and other owners.

The state of the Latvian countryside was also affected by the Stolypin agrarian reform in Russia, the goal of which was to form farmsteads and farms separated from the community, by transferring them to private farmers. The reforms were aimed at ensuring the creation of the middle class in the countryside. The full reform was also aimed at Latgale (before 1912, 14\% of farms were divided into farmsteads). In Vidzeme and Kurzeme, where there were no villages, farms could receive big loans. Riga Central Agricultural Society was founded (it received state grants) and co-operative society-Latvian agricultural economic society that contributed to the rational management of the farm, facilitated agricultural machinery and fertilizer purchase, butter export, as well as being responsible for the promotion of agricultural education. In 1913, in Priekuli the first Latvian agricultural experimental station was founded (Strods, 1992).

The Republic of Latvia paid special attention to the development of the agricultural sector. Peasants were granted long-time loans for purchasing construction materials and inventory, and were provided with beneficial import and export tariffs and other tax incentives. In comparison with other European countries, on average, the harvest in Latvia was low; however, in 1933, the country fully supplied itself with grain, and in 1934 began to export it (87 thousand tonnes of rye and 30 thousand tonnes of wheat). In the late 1930s, grain farming and crop production accounted for around $33 \%$ of a farmers' income, farm animal production- $51 \%$. It later became the main agricultural sector and enjoyed a very successful development. The extensive network of agricultural communities also contributed to rural development. In 1935, the Chamber of Agriculture closed part of these communities and, in accordance to the Chamber's statutes, formed one community for each district. Dairy product manufacturing was especially significant for dairy farming communities (in 1925, there were more than 100, in 1937-around 300). In a short time, processed milk volume in these society communities' dairies doubled (in 1937-approximately 547 thousand tonnes of milk, produced approximately 22 thousand tonnes of butter). Much attention was paid to farmed animal breeding and cultivation. In 1938, Latvia, as a milk (mainly 
butter) and meat (mainly bacon) product exporter was in fourth place in Europe (after Denmark, the Netherlands, and Sweden). Mechanisation levels in farms was relatively low, therefore in the 1930s, the agricultural sector employed seasonal workers from abroad (mainly from Lithuania and Poland; in 1936 approximately 48 thousand people in total, and in 1938-37 thousand people) (Tilde, 1998-2012).

After the proclamation of independence on 18 of November, 1918, Latvia needed a new financial system and national currency. In order to implement a successful monetary policy, on the 7th of September, 1922, the Constituent Assembly adopted a law on the establishment of the Bank of Latvia, which had been granted emission rights. Its temporary statutes were confirmed on the 19th of September, 1922, by the decision of the Cabinet, and its initial capital was 10 million lats. The bank was founded on the basis of a State Savings and Credit bank, with the Bank of Latvia taking over its assets and liabilities in 1922. Already on the 2nd of November, the Bank of Latvia put into circulation temporary 10 lats banknotes - 500 Latvian rouble banknotes with imprint. The Bank of Latvia performed both direct national central bank note-money emission, security and control of its circulation, and commercial activities by financing and providing loans to state and private companies, establishments, and citizens.

On the 24 of April, 1923, the Latvian Saeima plenary session approved the Statutes of the Bank of Latvia, which were signed on the 2nd of July by the then president Janis Cakste. The Bank was managed by the council and management board. The Council consisted of the Chairman, Deputy Chairman, and 11 members, but the board also included the managing director, his deputy, and three directors. The first Chairman of the Council was the minister of finance Ringolds Kalnings. In 1926, the economist, Member of Parliament and director of Riga Diskont bank, Julijs Celms became the next Chairman of the Council. In 1931, he was replaced by Adolfs Klive, who led the Board until 1940 (Latvijas Banka, 2014).

The war and post-war period brought significant changes to the Latvian economy, therefore, after regaining its independence in 1991, it was difficult to instigate competitive economic activity. Previous sources of raw materials and outlet markets in the former USSR were lost and obsolete equipment and technology prevented the production in Latvia of products for the world market. The situation was aggravated by the slow and poorly organised privatisation of state enterprises, which only began in 1995 . These factors led to a contraction in industrial production, causing unemployment. Wood processing and food production industries were in the best positions, as they mostly used local raw materials.

Presently, wood processing is one of the largest Latvian industries and this grew rapidly in the post-independence period, however, in the last year this growth has stalled. Food production is the second largest Latvian industry and forms one fifth of total value added manufacturing. Approximately $75 \%$ of its production is consumed by the local market and the rest is exported. Accession to the EU increased the demand for Latvian food sales in all directions - in Russia, CIS, and EU countries. The export of metal and metal processing industries is almost $80 \%$. Approximately, only one fifth of the light manufacturing (textile and leather products) stays in Latvia. Most products (three-quarters of the total production) are exported to European Union countries.

In many industries - wood processing, automotive, metal processing, printing, etc., it was foreign companies who began the manufacturing and export of such products from Latvia. Latvian entrepreneurs themselves did not start or will not be starting in the near future.

Availability of structural funds for Latvian enterprises allowed for a greater scope in the realisation of business ideas and problem-solving, which had previously impeded an increase in production volume, and hence, served to increased exports. 
Presently, transit plays an important role in the Latvian economy. Despite the fact that this sphere can be affected by various external economic risks, it amounts to 1/5 of the Latvian GDP (Tilde, 1998-2012). Implementation of the euro on the 1st of January 2014 strengthens Latvia's position on international markets and projections indicate that the introduction of the euro will increase investment in Latvia. The Latvian economy is considered as one of the fastest growing; however, this growth can be threatened by various internal and external risks.

\section{TOP Industries in Latvia According to Annual Turnover Figures}

In the 1990s, entrepreneurs emerged as an important new force in Latvia. "They constituted about 95 percent of all registered businesses at the start of 1993 and employed some 20 percent of the Latvian workforce" (Martinsons \& Valdemars, 1992). After the collapse of the Soviet Union, "growing numbers of people faced the prospect of starting their own businesses, as state enterprise jobs disappeared" (Martinsons \& Valdemars, 1992). Many companies that got established at those times are still operating to the present day. For example, Grindeks (pharmaceutical products), Elko (commodity products), Latvijas Balzams (beverage wholesale and production), Akselss (fuel retail and wholesale), and Severstallat (metal processing), etc.. Latvian enterprises operate in various industries.

The present article concentrates on the analysis of the TOP 500 companies in Latvia (according to their turnover data in 2012). The list was published by "Dienas Bizness" business newspaper. In order to better qualify the analysis for the present article, these companies were divided into those with a turnover exceeding 50 million euro per annum (large companies) and those with less turnover (medium companies). The figure " 50 " was taken from the European Commission recommendations on Small and Medium Enterprises (SME). According to EC, SMEs are "enterprises which employ fewer than 250 persons and which have an annual turnover not exceeding 50 million euro, and/or an annual balance sheet total not exceeding 43 million euro" (Extract of Article 2 of the Annex of Recommendation 2003/361/EC). It has been a consensus among the academics and researchers that there is no uniform definition for an SME nationally or internationally and definitions vary from country to country (Mohibul \& Alejandra, 2008).

After analysing the data on turnover in the year of 2012 for both large and medium companies in Latvia by applying the comparative research method, it is discovered that the 10 largest industries for the big companies are: fuel retail and wholesale (approx. 3,605 bil euro.), energetics (approx. 1,821 bil. euro), food retail and wholesale (approx. 1,689 bil. euro), chemical products (approx. 1,519 bil. euro), logistics (approx. 1,235 bil. euro), metal processing (approx. 1,019 bil. euro), financial services (approx. 896 mil. euro.), information technologies service and production (approx. 857 mil. euro), passenger transportation (approx. 705 mil. euro), and telecommunication services (approx 539 mil. euro). For medium companies such industries are: food retail and wholesale (approx 1,365 bil. euro), logistics (approx. 842 mil. euro), fuel retail and wholesale (approx. 657 mil. euro), wood processing (approx. 521 mil. euro), automotive industry (approx. 466 mil. euro), construction (approx. 451 mil. euro), financial services (approx. 355 mil. euro), pharmaceutical products (approx. 276 mil. euro), metal processing (approx. 273 mil. euro), and beverage wholesale and production (approx. 252 mil. euro). Industry leaders in both large and medium companies that coincide are:

- Food retail and wholesale;

- Logistics;

- Fuel wholesale and retail; 
- Financial services;

- Metal processing.

The acquired information proves our fourth hypothesis that both large and medium companies have specific business sectors with the highest turnover levels that coincide. According to Martinsons and Valdemars, who conducted research in the present sphere in 1992, Latvia's income has always been dependent on industrial spheres and agriculture (see Table 1).

Table 1

Composition of National Income in Latvia

\begin{tabular}{llc}
\hline & $1938(\%)$ & $1989(\%)$ \\
\hline Industry & 27 & 45 \\
Agriculture & 38 & 25 \\
Construction & 7 & 8 \\
Transport & 10 & 8 \\
Trade and other & 18 & 14 \\
\hline
\end{tabular}

Note. Source: Martinsons and Valdemars (1992) and Spekke (1957).

"Agriculture and forestry, as well as a broad service sector, are likely to be the life-blood of a successful Latvian economy (Martinsons \& Valdemars, 1992). Meat and dairy products each accounted for over 10 percent of the total economic activity. In the earlier period of independence, per capita butter and bacon exports ranked Latvia among Europe's top three countries, while agriculture and forest products each made up over 30 percent of total exports (American Latvian Association, 1968, p. 30).

The performed analysis in the present paper shows that these industries remain popular in the 21th century. Industry leaders for large, medium and small companies - food retail and wholesale, logistics and metal processing remain the same as in the 20th century. However, in present century, they are joined by two other leaders-financial services and fuel retail and wholesale.

\section{Latvian Target Sectors for Potential Investments}

During three years, LIAA (Investment and Development Agency of Latvia) researched world economic trends, Latvia's potential and expertise. As a result, eight target sectors based on competitive advantages of Latvia were established. LIAA states that the following industries have potential foreign investment opportunities:

- Information technology (incl. SSC/BPO/Data Centres);

- Green technology;

- Healthcare;

- Life sciences;

- Transportation and logistics;

- Metalworking, machinery and electronics;

- Woodworking;

- Food processing (Investment and Development Agency of Latvia (LIAA), 2014).

The agency has conducted their own research on the following industries in Latvia and demonstrates its key advantages for each particular business sector. The authors of the paper have systematised the information provided on the LIAA website by composing Table 2 "Key advantages of investing in Latvian industries". It presents useful information to potential investors who are willing to invest in Latvian business sectors. 
Table 2

Key Advantages of Investing in Latvian Industries

\begin{tabular}{|c|c|}
\hline Industry & Key advantages \\
\hline Information technology & $\begin{array}{l}\text { - Skilled labour force and high investment in tangible assets contribute to productivity } \\
\text { - Western-style working culture } \\
\text { - Well-developed export market } \\
\text { - Hnowledge of foreign languages among IT professionals } \\
\text { - Low electricity prices for industry } \\
\text { - Supportive government policies }\end{array}$ \\
\hline Green technology & $\begin{array}{l}\text { - Supportive government policies and EU initiatives } \\
\text { - Long-standing experience and expertise in the generation of energy from renewable sources } \\
\text { - Leading exporter of renewable energy sources in the EU } \\
\text { - Lowest energy intensity in Central and Eastern Europe } \\
\text { - Low energy prices } \\
\text { - Potential to decrease energy dependence on Russia } \\
\text { Abundance of natural resources }\end{array}$ \\
\hline Health care & $\begin{array}{l}\text { - Recent efforts to improve efficiency } \\
\text { - Highly qualified workforce at competitive cost } \\
\text { - High standard of health services } \\
\text { - Promising new business opportunity: medical tourism }\end{array}$ \\
\hline Life sciences & $\begin{array}{l}\text { - Strong R\&D capability } \\
\text { - Established manufacturing infrastructure } \\
\text { - Geographical proximity to Eastern markets } \\
\text { - Song-standing tradition in chemistry } \\
\text { - Skilled and competitive workforce }\end{array}$ \\
\hline Transportation and logistics & $\begin{array}{l}\text { - Historic transport and trade gateway } \\
\text { - Access to Russian and European markets } \\
\text { - Excellent infrastructure } \\
\text { - Freight volumes projected to increase } \\
\text { - } \text { Riversified alternatives; no bias towards road transport } \\
\text { - Riga International Airport is a regional hub } \\
\text { - Competitive labour }\end{array}$ \\
\hline $\begin{array}{l}\text { Metalworking, machinery and } \\
\text { electronics }\end{array}$ & $\begin{array}{l}\text { - Traditionally a leading sector } \\
\text { - Easy access to raw materials due to an advantageous geographic location } \\
\text { - Excellent logistics infrastructure } \\
\text { - Competitive labour force } \\
\text { - High competitiveness in higher value products } \\
\text { - She of the lowest electricity prices across the EU } \\
\end{array}$ \\
\hline Woodworking & $\begin{array}{l}\text { - Traditionally strong sector } \\
\text { - Easy access to raw material } \\
\text { - Abundance of skilled labour } \\
\text { - High private investment in R\&D } \\
\text { - Supportive government initiatives, focused to facilitate innovation and encourage higher value } \\
\text { - Industry's sustainability }\end{array}$ \\
\hline Food processing & $\begin{array}{l}\text { - Robust supply chain } \\
\text { - Access to quality ingredients } \\
\text { - Ecological agriculture for natural ingredients } \\
\text { - Abundance of skilled and competitive labour } \\
\text { - Developed transit infrastructure }\end{array}$ \\
\hline
\end{tabular}

Note. Source: Authors' table. 


\section{An Opinion on Economy Crisis in Latvia}

Since the authors of the paper try to analyse and define critical-to-success factors of Latvian enterprises, it should be noted that during the period of rapid economic growth, the majority of companies in small, medium and large businesses were successful one way or another. It was enough to register a company and to have skills in a craft for a business to develop. To earn equity was difficult at all times; moreover, during the period of economic growth, having profit was not impressive: The majority of enterprises were profitable. Thus, CSF could be defined. During the period of economic growth, these factors were unclear, reminiscent more of Monet works rather than Durer's.

Until the appearance of economic recession in Latvia, in August of 2008, there was a period of global economic growth that seemed endless to the majority of entrepreneurs. The authors assume that the upturn in the economic cycle of the country can be traced back to 1995, with the arrival of first Western investors to the country, and continued up to the year 2008. Thus, during these 12 years, entrepreneurs had positive prospects. The only thing disturbing this was global crises — as an example - the Russian default of August 1998, however, the economy quickly revived.

The period of rapid economic growth in the first years of the millennium was largely due to Latvia joining the European Union in May of 2004. This was a strong impulse to enhance the attractiveness of the economic climate in the country and led to the influx of investors. In reality, it was not only the classic economic development, but also the speculative rise in prices in most sectors, as foreign entrepreneurs initially invested in the country for the purpose of short-term resale of assets and businesses. In the German language, there is a term "hartgesotten", which means "hard-boiled", an investor that puts money into country's economy, counting on a global perspective, from 35 years and above. No matter what happens to assets in the short-term, the investor will not be willing to sell them, as they are confident in their choice of investment object. The authors also assume that the majority of Latvian investors belonged to the second "zitterig" group ("shaky" investors) that were performing their business with only the goal of short-term resale, and any event could critically and globally change their strategy, for example, in the elite real estate project in Riga, called "Tomsona Terases", one flat was resold five times in one year. This was not an isolated case. The situation with the majority of real estate objects and businesses was the same. This leads to a conclusion that investments were short-term resale, for the purpose of instant market skimming.

In the year of 2013, famous Latvian politicians held the view that crisis is a fictional phenomenon, that it could be referred to a "crisis in one's mind", and that in reality, the situation is not as complicated. In this case, the authors cite Upton Sinclair's words: "It is difficult to get a man to understand something, when his salary depends on his not understanding it". For this reason, the authors try to correct "the success story of the country" and to target it, not at the whole region, as a separate republic, but at stories of success of certain companies and specific businesses.

The cause of crisis in Latvia should be searched for across the seas. As German speculators say, when New York sneezes, Frankfurt catches cold. Common features of the Latvian crisis are not much different from other EU countries like Greece, Spain, and Italy that are caught in a difficult situation.

In the developing crisis situation, many enterprises, operating in almost every industry, faced the threat of bankruptcy; some of them were forced to close. Companies performing business in the sphere of marketing and commerce, as known to the authors, has survived, mainly due to a reorientation towards the export of services; 
specific segments of health care, first of all supported by enterprises on the basis of financing insurance, also went bankrupt. Many real estate companies were shut. The crisis painfully hit the labour market forcing 300,000 Latvians to look for work in other European countries, mainly the United Kingdom.

Nevertheless, many enterprises have survived and successfully continue their existence. In the present article, the authors scrutinise these critical-to-success factors that helped them in overcoming the crisis.

\section{Historical Background and Specification of the CSF in Terms of Latvian Business Enterprises}

Actively starting with the second half of the 20th century, business organisations commenced to rely on critical-to-success factors in order to define and distinguish factors that are important for business decision-making. Such factors may be a system, programme, project, process or a set goal.

The initial concept of CSF was developed by Rockart and the Sloan School of Management, with the phrase first used in the context of information systems and project management (Rockart, 1982). Rowlinson (1999) has stressed that CSF are those fundamental issues inherent in the project, which must be maintained in order for team work to take place in an efficient and effective manner. They require day-to-day attention and operate throughout the life of the project.

CSF can be used at all levels of the organisation. They can stem from internal improvement initiatives, such as a need to improve workplace efficiency, or originate from external forces - changes in technology, legislation, or a stealth attack from the competition (Howell, 2010). An important fact is that CSF are the motivators but not the initiators of its kind, they can be used to enhance, rather than supplant, organisational improvement initiatives already in place.

The start of CSF research can be tracked from 1961, when Daniel (1961) first began discussing enterprise success factors in management literature. He concentrated on literary works related to production, which is relevant to any company in various industries.

In his paper on management of crisis in information systems, Daniel pointed out that a company information system must be discriminating and selective. It should focus on "success factors". He also stated that in most industries there should be three to six CSF that determine success. In the framework of the present research this statement is also confirmed.

Representing one of the most frequently-cited definitions in the literature, Rockart uses ideas from Daniel (1961) in defining CSF as "the limited number of areas in which results, if they are satisfactory, will ensure successful competitive performance for the organization". Consequently, he highlights the fact that these particular areas of activity should be constantly and carefully managed by a company.

CSF can be used as a means to establish management information requirements, to define information to be managed, and above all, to identify the crucial factors that must be addressed for an organisation to do well (McPherson \& Nunes, 2006). In generic terms, CSF can be defined as “...those handful of things that, within someone's job, must go right for the organisation to flourish" (Robson, 1994), indicating that these are factors that the manager should follow. In policy terms, they are described as "...those components of strategy where the organisation must excel to outperform competition" (Johnson \& Scholes, 1993).

According to Brotherton (2004), CSFs are the factors that must be achieved if the company's overall goals are to be attained. They may be derived from the features of a particular company's internal environment, i.e., its products, processes, people, and possibly structures, and are a reflection of a company's specific core 
capabilities and competencies critical for competitive advantage (Berry, Seiders, \& Gresham, 1997). However, the CSFs facing any given company will also be determined by the nature of the external environment it faces. One feature of these external CSF's is that they: “....are less controllable than the internal ones, though they may still be subject to varying degrees of measurement and control" (Brotherton \& Shaw, 1996, p. 115). Rockart (1979) also categorised CSF's into short-term (monitoring) and long-term (building) activities and demonstrates the four types of CSFs:

- Industry (factors specific to a particular industry);

- Strategic (factors specific to an organisation's particular strategy, developed for competitive advantage);

- Environmental (external influences, such as technology advancements, the economy, and political or regulatory actions);

- Temporal (factors arising from short-term situations and forces internal to an organisation).

A successful CSF that covers the entire organisation should include all four types. There are two options for defining CSF: The analysis of enterprise planning documents and interviews with the top-managers of the companies, performed by the Forbes Latvia magazine. The following six crucial CSFs of Latvian enterprises were defined during the research: specific market niche, exporting activities, technological innovations, team work, high-quality manufacturing, and IT sector significance.

\section{Specific Market Niche}

According to Garvin (1984), a particular dimension of quality in which an industry claims to be superior or excellent, is responsible for creating a market niche of the product. A small but profitable segment of a market suitable for focused attention by a marketer. Market niches do not exist by themselves, but are created by identifying needs or wants that are not being addressed by competitors, and by offering products that satisfy them (Business Dictionary, 2014). When choosing a specific market niche, an enterprise is offering a certain product or service that is currently not offered by other companies, or offered at a superior quality. Such a marketing move dramatically reduces the chances of competition among other enterprises that are offering some type of goods and services. No competition or low competition allows a company to set their own prices. In such cases, they do not depend on the price of similar products offered by their competitors. By operating in a certain business segment, a company positions itself as a leader, so when new players join the market, the customers will already be used to the leader. This is the most popular CSF implemented by the interviewed companies.

\section{Exporting Activities}

To export means to "send goods or services across national frontiers for the purpose of selling and realizing foreign exchange" (Business Dictionary, 2014). According to our research, exporting activities take second place among the most popular CSFs. Even if the produced goods or services are not in demand in the country, where the head office of a company is located, they can still be popular on international markets. Export allows enterprises to broaden its activities, to join new markets, and sell goods that are more in demand in other countries, etc.. It opens a great variety of opportunities for businesses, especially for small and medium ones, as they "tend to move into foreign markets mainly as exporters because exporting is the cheapest, simplest and quickest way to achieve internationalization" (Leonidou, Katsikeas, \& Coudounaris, 2010). The majority of enterprises, for which interviews are scrutinised in the present paper, belong to the SME category. For some, exporting activities is the only way to continue their business. 


\section{Technological Innovations}

Technological innovations are "new knowledge or know-how employed to develop or manufacture a product service" (Capon \& Glazer, 1987). Such innovations help in increasing the quality of goods and services, sometimes allowing a company to create a unique product, which can be only achieved by applying these innovations. By implementing technological innovations, companies can achieve customer loyalty, as they will be seen as a developing enterprise that provides high quality or unique services. Technological innovations can also help conquer new business segments and even form the basis of new products. This CSF takes third place in the present research.

\section{Team Work}

Team work or "the activity of working well together as a team" is fundamental to the success of business (Oxford Business Dictionary, 2006). When people come together to form teams, shared knowledge and thinking expand beyond the individual, problem-solving becomes easier and production rises. Team spirit and competition are motivating factors but the team shares a common goal to succeed, supported at all levels of the business. The same two people working together as a team are twice as productive as when working independently. Successful businesses are typically team driven. As part of a team, an individual can still apply themselves, bringing their own expertise and knowledge to a task but they will also personally benefit from working with other team members who may have different skills.

\section{High Quality Manufacturing}

In the post-crisis business world, manufacturing businesses are presented with a stark choice between offering cheap, mass produced goods for general consumption or higher quality products that may cost more to manufacture and have a limited customer base. The danger in relying on quality alone is evident in the number of smaller companies that did not survive the crisis, when their customer base disappeared, often opting for cheaper options to save money. The inverse can be seen in the rise in manufacturing imports of cheap products from China and other countries, where labour and material costs are significantly cheaper. Companies with high quality manufacturing ethics must therefore endeavour to foster greater loyalty and respect among their customers to survive difficult financial times. Our research proves this statement, as this CSF is among top five factors that are critical to success.

\section{IT Sector Significance}

Petroleum and automotive companies claim the highest individual net worth, but the IT sector effectively shapes world business. Familiar names such as Apple, Google, eBay, Facebook, and Microsoft are a part of our daily lives but beyond this there are the smaller businesses who specialise in everything from code and app development to statistical and data analysis, internet and E-commerce. These businesses can start-up with relatively little overhead costs and grow quickly to become even a Fortune 500 company in a fraction of the time of traditional industries. The IT sector has an abundance of entrepreneurs who's forward thinking ideas and contributions can often be of global significance. The significance and importance of the IT sector to economies cannot be overstated and growth is exponential. IT companies are well equipped and flexible to weather a financial crisis but certain sectors, such as social media and personal technology are also vulnerable to the fast paced development of competitors and are at the whim of the public. According to our research, the present CSF is among the most popular factors. 


\section{Critical Success Factors-Research Findings}

Figure 1 is created and based on 72 articles from Forbes and Dienas Bizness magazines in Latvia, describing how Latvian companies survived the economic crisis that started in 2008, including interviews with either proprietary or top management of those companies. The authors of the paper analysed Forbes magazine archive from 2010-2014 totalling 38 magazines. Following selection of the articles, each of them was thoroughly scrutinised and 30 critical success factors (CSF) were defined. These factors are divided into two sections-primary and supplementary. After summarising the results, a CSF figure was created in order to reflect the studied case situation.

According to the CSF figure (see Figure 1) the evident leading critical success factor is a specific market niche. There are 72 companies operating in 52 different industries and 28 of them (38\%) named this factor as crucial or determinative. By selecting a certain niche, a company can decrease the level of its competitors. On occasion, if a product or service is very specific, as in the case of "Daba laba", "ISP Optics Latvia", and "Raksi", there are no competitors. During a crisis, this factor is especially important, as clients will not move to competitors in case of price increases. Another benefit of selecting a specific niche-a company can concentrate on a certain product, making it more qualitative. The majority of 28 companies (26) highlighted this factor as primary.

Export takes second place on the scale of importance among CSF-24 companies emphasised this factor (31\%). Sixteen out of 21 companies named this factor as primary. If a company did not succeed in finding a specific niche or that niche is not in demand in a certain country - other markets can provide an entrepreneur with such opportunity for business. In the present study, technological innovations take third place (14 companies marked this factor as important). Half of these companies consider this factor as primary. Technological innovations allow providing more qualitative or unique services and goods. Four out of 14 companies, who highlighted technological innovations as an important factor, also mentioned "high-quality product" factor as critical to their success in business. Fourth place is taken by team work factor, which was highlighted by 13 companies. High quality of products follows with 12 companies mentioning it as a critical success factor. IT factor takes sixth and price/quality policy achieves seventh position according to our figure. B2B collaboration (business to business) takes eighth place. Some companies (for example, "Jums" apparel company) state that without B2B they would not achieve the same results and development as they presently have. B2B collaborations allow making large steps forward, saving years of development. Reinvesting profit, customer relationship marketing (CRM), green marketing, unique product assortment, costs' optimisation and E-commerce share ninth place. Logistics and location factors were mentioned as significant by five companies and taken for tenth place. Eleventh place is shared among diversification in activities, recruitment policy and first-mover advantage critical success factors. Remaining CSFs have been chosen by less than three companies each. However, half of them are stressed as primary and the other half is considered supplementary by the interviewed companies.

Our first hypothesis is confirmed partially. Export is among the most significant critical success factors; however, it is not primary. Finding a specific niche is seen as more critical by the interviewed companies. Our second hypothesis has been proven wrong, as government funding was mentioned only once as a supplementary CSF. The third hypothesis has also been proven wrong, as during the research, 30 critical-to-success factors were named in the interviews. 


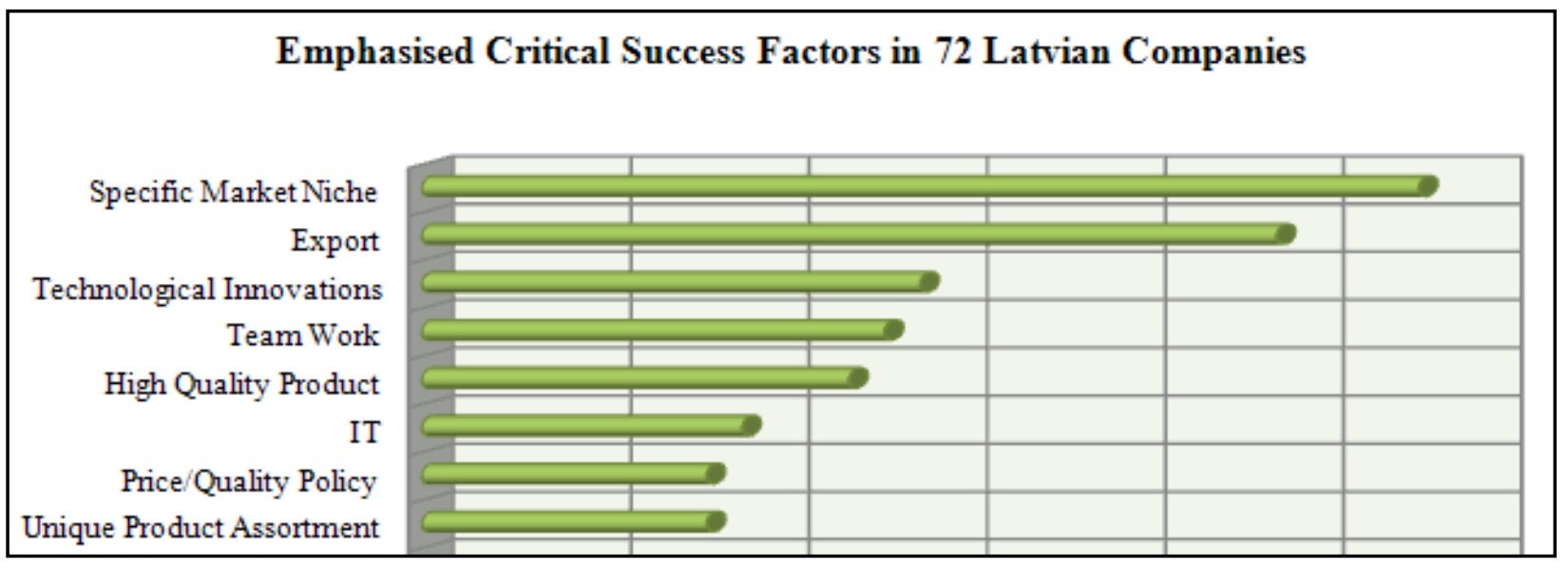

Figure 1. Emphasised critical success factors.

\section{In-Depth Interviews With the Top Management of Six Companies in Latvia that Survived the Economic Crisis in 2008}

Top management representatives of large Latvian business entities were interviewed by GFK (Custom Research Baltic agency) on behalf of the authors of the paper. These companies were selected based on their responsiveness and availability. The interviewed Latvian companies operate in various industries from chocolate manufacturing to real estate value improvement. All those interviewed were given a list of $30 \mathrm{CSF}$ that were carefully selected by the authors of the paper. Interviewees were asked to rate each factor on a scale of 1 to 5 with the highest evaluation of 5 points indicating an "absolutely critical" factor while a value of 1 indicates a factor viewed as "irrelevant".

\section{SIA Metrum}

Metrum enterprise is operating in various spheres of real estate business, more precisely - real estate value improvement, which deals with planning through to air quality data acquisition (for nature conservation, etc.). The interview was held with Maris Krievs, who is the member of the board of SIA Metrum. Maris is responsible for the company's finances and development. The company has been operating for nearly 10 years. Metrum was founded in 2005, before the crisis, when the financial climate in Latvia was seen as healthy and expanding.

Maris lists 12 CSF that are marked as very significant to the company. These critical-to-success factors are: effective management, outsourcing, first-mover advantage, diversification activities, CRM, unique product assortment, IT, high quality product, team work, technological innovations, and specific market niche. However, he also highlights his TOP five CSF from among the above mentioned. The first place belongs to the high quality of products. Second place is taken by unique product assortment, which is followed by team work, CRM and learning organisation, which, in his opinion, is related to customer relations management. The following CSF were marked as irrelevant-B2B collaboration and franchising.

Green marketing, pricing policy, costs optimisation, and recruitment policy factors were each given 2 points out of 5, or viewed as relevant but not as significant as other above mentioned ones.

Export was given 4 points out of 5, marked as critical, however, in the interview it is highlighted that export is very important for the sphere in which Metrum operates. Export has also provided additional income to the company and helped them to retain several employees during the financial crisis; however, the company was still forced to optimise human resources. 


\section{SIA Karavela}

The following fish processing enterprise was founded in the year 1882; however, it has only been known as Karavela since 2003. The company has already dealt with economic crisis before, in 1998 and was forced to cease its business activities. Nevertheless, it reopened in 2002 and followed a successful road of redevelopment. During the following 10 years, Karavela's turnover grew from four million to 32 million (in 2013).

The interview was held with Andris Bite who is the co-owner of the enterprise. He states that previous negative experience in fighting the 1998 crisis has helped the company to fight the last crisis (in 2008), as the management had no illusions about the recession and was ready for the hit. Andris also stated that the company did find positives in the 2008 crisis, as there was an increase in employees willing to work in the industry.

Another very significant fact is that Karavela is predominately an exporter and as such, the economic situation in Latvia has relatively little effect on the enterprise. Karavela exports to 46 countries. The Latvian market accounts for less than 5\% of turnover. The most profitable foreign market is the Russian Federation. The company pays significant attention and puts much effort into adapting to foreign markets in order to be successful. Andris says that it is about individual preferences of customers in different countries: "You need to make exactly what they want and what they eat. Then you can become a player on their market".

The next CSF is business to business collaboration, as Karavela established a very successful cooperation with one local enterprise that was forced to liquidate their production, as operating costs, for example, in Denmark, was too high. In order to stay in the market the company joined with Karavela and Karavela started to produce for that local enterprise. With time that enterprise became Karavela's representative and recommended it to the foreign market. Karavela needed those recommendations as it brought about future cooperation with other large businesses.

Another significant matter is to visit all the exhibitions in which you can be noticed by other local companies. Karavela has participated in these exhibitions for approximately 10 years. The company receives government funding, which covers $100 \%$ of the exhibition costs. However, the government factually covers only $25 \%$ with the remaining $75 \%$ being assured through EU funding.

Andris also highlights that mechanisation is also an important factor, as the cost of human labour including all the taxes is very expensive. Investing money in robots may soon pay off, keeping the costs down. Personal involvement in company's management according to Andris is also of great importance.

The co-owner of Karavela marked six CSF that are absolutely critical: high quality products, learning organisation, CRM, team work, technological innovations, export and market diversification, which is a new CSF added to our figure by Andris himself. High quality products are especially stressed, it is the value of the company. As previously mentioned, export is of vital importance. Mechanisation can be referred to as technological innovations. Reinvesting profit is also marked as very significant in the interview; however, in the figure it was marked 4 out of 5. Franchising, e-commerce, and marketing innovations were marked as irrelevant. Unique product assortment, advertising, recruitment policy, first mover advantage and logistics were given 2 points out of 5 , which makes these factors relevant but not as important or critical as others that received higher marks.

The enterprise takes 420th place in the TOP-500 Latvian companies according to their turnover (20.505 million euro in the year 2012). 


\section{SIA Madara Cosmetics}

SIA Madara Cosmetics is a relatively young company; it was founded in 2006, just two years before the economic crisis. During the last four years its turnover grew by 38\%, half of which was earned from exporting to the Netherlands, Japan, South Korea, China, Sweden, and many other countries. The enterprise produces and sells cosmetic products. Madara as a brand is already recognised not only in Latvia but also in Finland. The interview was held with Anete Vabule, assistant director of the enterprise.

In 2008, the year the economic crisis began, Madara Cosmetics acquired Eko certification that confirms its cosmetic products are of high quality and made of natural products. This event opened new markets for the enterprise, as distributors started to trust Madara Cosmetics and this subsequently increased the volume of exports. Therefore, in that year the company was growing.

Anete highlights the importance of being flexible as a company, as a key to success. It is easier to overcome crisis situations, when you can adapt and change the way of performing business activities. High quality products are marked as of great importance 5 out of 5 . Anete stated that the above mentioned CSF is the company's number one success factor. There are 10 CSF that are marked as absolutely critical: high quality products, team work, unique product assortment, export, e-commerce, flexibility, logistics, CRM, effective management, and learning organisation. Franchising and unique servicing assortment was market as irrelevant critical-to-success factors. Diversification of activities as well as recruitment policy CSF was given 2 points out of 5 , which means that they are relevant but not of great significance. The company is also using EU funds for the purchase of necessary equipment; however, the present CSF was marked 3 out of 5. According to the company's assistant director, logistics is seen as a factor with the same importance as export activities.

As with Karavela, Madara Cosmetics enterprise stresses the necessity to participate in international exhibitions, where a company can establish beneficial networks, cooperate with other businesses, and get noticed by local enterprises.

\section{SIA Brain Games}

SIA Brain Games (formerly "Prata speles") was founded in 2004, also not long before the 2008 economic crisis. The company's business activities include the wholesale and reproduction of board games, as well as development and production of their own board games. Production began during or just before the crisis, as the head of the enterprise Egils Grasmanis states.

Business activities were not seriously affected by the economic crisis; however, Egils remembers: “...we had a point, those four years ago, when we almost had to shut down, as the financial situation was very, very difficult". He explains it as possible errors in financial planning and the lack of financial control, as well as decisions, based on emotions. Egils then highlights that Brain Games is only still in existence due to the enthusiasm of the management and company's employees. Only those with a passion for board games were recruited. Despite the critical financial situation, the head of the enterprise made a decision to take even bigger risks and they eventually paid off.

During the interview, Egils marked $11 \mathrm{CSF}$ as absolutely critical: High quality products, market niche, B2B collaboration, unique product assortment, team work, export, profit reinvestment, recruitment policy, flexibility, CRM, and learning organisation. Among them, a TOP five CSF were selected-high quality product, market niche, team work, CRM, and learning organisation. 
The following CSF from the top 30 list were marked as irrelevant: franchising and government funding. Diversification in activities, unique servicing quality, e-commerce, and marketing innovations were marked as insignificant.

Brain Games is an absolute niche product. Export is given 5 points out of 5; however, Egils stated that it was not this CSF that helped it survive the 2008 crisis, he also adds that there were no such physical factors, it was faith in the business and the ability to overcome the recession, as well as taking even higher risks.

\section{SIA NP Foods}

The present company consists of three Latvian companies-AS Laima (confectionery and sweets wholesale production), AS Staburadze (confectionery and sweets production), and AS Gutta (non-alcoholic drinks production). NP Foods performs confectionery and sweets wholesale, management, purchase, sales and marketing of the Laima, Staburadze, Gutta brands, and other companies. It was founded in 2009, during the crisis. The interview was held with NP Foods's export department head, Ieva Jonsone.

In 2009, the company's goal was to operate without losses. Ieva stated that there were pluses in the crisis, as you then turn to restructuring and fully concentrate on your activities in order to improve them. NP Foods reached that goal and even showed growth. During the economic crisis, unpopular decisions had to be made such as the consolidation of administrative resources, a 24 day limit imposed for raw material storage and car fleet reduction.

The next years, 2010 and 2011 were also years of consolidation, which allowed the company to stay on its feet and achieve further growth. The company started to pay more attention to inform people about their brands, for example, SIA Laima celebrated its 140 anniversary in 2010. Laima has been an exporter since 1870.

Ieva also stated that export is not the remedy for crisis, as "nobody is waiting for you" in other foreign markets. It is a long process, as you must "do your homework" before you enter a market, as you will only see the results after three-four years. Here another CSF comes into force-government funding for international exhibitions. In the case of NP Foods, it is EU funding, managed by the Ministry of Economy of Latvia and LIAA. The NP Foods export department head also highlights in the interview that it is very important for the brand to be recognised on the foreign market. This is a long-term process. Neighborly relations are also important for success in export transactions.

It is extremely important during a crisis not to reduce the quality of your product quality, otherwise you can lose the market completely. It is very difficult to maintain a good reputation.

Ieva marked $11 \mathrm{CSF}$ that are absolutely critical: high product quality, B2B collaboration, unique product assortment (especially in the framework of export), technological innovations, profit reinvestment, flexibility, logistics, research and development, CRM, government funding and another, new CSF-brand and values.

Specific market niche, marketing innovations, and first-mover advantage are irrelevant. Green marketing was given 2 points out of 5, which makes this CSF relevant, but not as significant and critical, as others.

The company is present in the TOP 500 companies in Latvia, according to their turnover in 2012, and takes a high position - number 94, with a turnover of 42,844 million euros. In the previous year, 2011 it ranked 103 place, proving the economic growth of the enterprise.

\section{SIA Cleanhouse}

The enterprise was founded in 1997, when there was almost no competitors, no specific market niche in this sphere. Cleanhouse provides cleaning services. Its initial name was "Atri un tiri" (which means "Fast and 
clean" in Latvian). Presently, the company has about 10 direct competitors and about 190 small competitors. The interview was held with Martins Drone who is the director of the enterprise.

He stated that in the field of cleaning services, the crisis is still present. There are too many market players preventing any increase to prices. As with Ieva Jonsone from NP Foods, Martins highlighted the fact that a high quality of service and products should always be present. He stressed that "It is one of the top factors that ensures successful and future development". For Cleanhouse, it is more important to provide a high quality service despite the possibility of larger losses from performing that service, but this is strategically beneficial. It is crucial to preserve a good reputation and loyal clients.

Cleanhouse, in the same way as other above mentioned companies is engaged in export activities. This year they have found new markets and new market niches. An interesting fact is that these activities started during the 2008 economic crisis. Nevertheless, Martins stated that the company could overcome the crisis without export activities, as there were simply new ways, new markets, and new experiences. He also highlighted the fact that during a crisis, one should focus on the market that is being affected by the crisis in order to keep and develop it. In the present case, when one enters a new market, attention is diverted to it which could otherwise be given to the market that is suffering more from the crisis. Martins stressed that it is possible that without export more attention, investments, etc., would be paid to the local market that faced recession, yielding more success.

Martins has marked TOP 7 CSF: The first place is taken by high product quality, which is followed by price/quality policy, team work, effective management, learning organisation, specific market niche, and diversification in activities. There are many CSF, marked as irrelevant by the director of Cleanhouse: franchising, green marketing, export, logistics, government funding, marketing innovations, location, first-mover advantage and outsourcing. B2B collaboration, unique product assortment, unique servicing quality, and $R \& D$ were marked as insignificant.

\section{Interim Summary}

On average, there are $10 \mathrm{CSF}$ for each company; however, the most strongly pronounced critical factor is high quality of products. All six interviewed companies have marked it as highly significant and gave it first place in their individual top 5s. High quality of products is an absolute leader among all CSF. This means that if an investor wants to start their business activities on the Latvian market, and then be successful, it is vitally important to manufacture high quality products and provide high quality services.

Specific market niche, which was number one CSF according to Forbes magazine interviews, is only critical to small companies, such as SIA Brain Games, as this is their way to enter new markets and grow. Large companies (NP Foods, Cleanhouse) note that specific market niche is not critically important; as these enterprises do not operate in a narrow industry (confectionary and cleaning services are not unique products/services).

Four out of six companies are using EU funds, mainly for participating in international exhibitions and for purchasing equipment. Four out of six companies (Cleanhouse, Metrum, Karavela, and Madara) also provided clear and define answers that they are either not using government funding, or that it was not given to them. Therefore, it is important to take into account that new businesses are more likely to receive financial support from the EU.

Two out of six companies, NP Foods and Karavela are present in the TOP 500 companies in Latvia, according to their turnover in 2012. 
According to the six in-depth interviews, there are seven leading CSF: High quality product ( 6 out of 6 companies gave this CSF 5 points out of 5), learning organisation (4 out of 6), team work (4 out of 6), CRM (4 out of 6), export, market niche, and technological innovations were stressed by 3 out of 6 companies.

\section{European Union Funds in Latvia}

As Latvia is a participant country in the European Union, its entrepreneurs have an opportunity to receive European funding for their business activities. In the present paper, EU funding is not listed as a critical-to-success factor. Nevertheless, EU funds can, sometimes, be a part of government funding, i.e., government will provide a business with financial support that will later be refunded to the government from EU funds.

The European Union funds Managing Authority in Latvia is the Ministry of Finance. This is responsible for effective and transparent implementation of EU funds according to principles of sound financial management (The Ministry of Finance, 2014). In Latvia, EU funds have an official website, which is administered by the Ministry of Finance.

The Managing Authority, in cooperation with responsible institutions and consulting with social, NGO and regional partners, develops EU funds programming documents thus ensuring compliance with the partnership principle in the development of programming documents, as well as ensuring intersectoral coordination of EU funds. The Managing Authority also performs functions of EU funds management, evaluation, communication management etc. (The Ministry of Finance, 2014).

During the years 2007-2013, Latvia received 4.53 billion Euros from EU funds, the European regional development fund, and Cohesion fund. Over 6000 projects were supported.

For the following seven years, 2014-2020, the EU will invest 4.4 billion euros from the above mentioned funds. An interesting fact is that Latvia is receiving four times more finances than it pays to the EU.

For the next seven years these 4.4 billion euros are planned to be invested as follows: $12 \%$ of the total amount into research, technological development and innovations, 5\% in e-management and services, $7 \%$ in the increase of SME competitiveness, $11 \%$ in the transition to economy with low carbon-stock emissions in all sectors, $13 \%$ in the protection of environment and resource efficiency, $27 \%$ in sustainable transport system, $13 \%$ in employment, labour mobility and social inclusion, and the last $12 \%$ in education, skills, and lifelong education.

Specifically for business and innovations, it is planned to support 4,700 micro, small and medium enterprises. An $11.1 \%$ rise is estimated in the proportion of innovative entrepreneurs, which should reach $40 \%$. The volume of Latvian exports in 2022 should reach 12,684 million euros. Risk capital investments will increase by seven times and in 2023 will be 15.6 euros per one person (The Ministry of Finance, 2013).

According to the information above, support for businesses is of least importance for the Ministry; however, it is among its available investments. Potential investors can still expect help from the funds.

Our six in-depth interviews with the top management of Latvian enterprises show that four out of six companies are using EU funds, mainly for participating in international exhibitions and for purchasing equipment. Four out of six companies (Cleanhouse, Metrum, Karavela and Madara) also provided clear and defined answers that they are either not using government funding, or that it was not given to them. Nevertheless, the EU funds are managed by the government. One of the interviewed companies, NP Foods, which is in the TOP 500 Latvian companies according to their turnover in 2012, marked government funding as 
absolutely critical factor, and in the interview they state that it is the EU funding, managed by the Ministry of Economy of Latvia and LIAA. Madara and Karavela (which is also in the above mentioned TOP 500) have marked government funding factor as significant, by giving it three out of five points. In their cases it is also the EU funding. Cleanhouse company that is using the EU funds, has not given government funding any marks. The authors of the paper can draw conclusions that the EU funds factor is critical, however, it is not of vital importance for the business.

\section{Successful Entrepreneurs in Latvia}

\section{Successful Entrepreneurs Worldwide}

Successful entrepreneurs are those whose business is bringing good profit that grows with each year. How well their business is doing, is shown and proven in the assets and annual reports. Frequently, the success is measured in millions. Therefore, entrepreneurs that are making millions in profit can be classed as millionaires.

Firstly, the authors of the paper shall concentrate on the term "millionaire". Business dictionaries provide simple definitions of the term. According to Oxford Business Dictionary, a millionaire is "a person who has a million euros, dollars, etc. or more; a very rich person" (Oxford Business Dictionary, 2006). Cambridge Business English Dictionary provides almost similar definition: "a person who has money, property, etc. that is worth at least a million dollars, euros, pounds, etc." (Cambridge Business English Dictionary, 2011). Depending on the currency, a certain level of prestige is associated with being a millionaire, which makes that amount of wealth a goal for some, and almost unattainable for others (Harris, 2007).

Millionaires are also called "high-net-worth individuals" or HNWI. Oxford Business Dictionary offers a rather short definition of the term "a very rich person" (Oxford Business Dictionary, 2006). According to Cambridge Business English Dictionary "high net worth individual: used by financial organizations to talk about a person who is considered very rich, especially one whose assets are in cash or can be easily sold for cash" (Cambridge Business English Dictionary, 2011).

Capgemini, one of the world's foremost providers of consulting, technology and outsourcing services, who provide World Wealth Reports in cooperation with other partners, based on their own methodology, defined high-net worth individuals (HNWI) as those with finance in excess of US\$1 million (around $€ 747,000$ ), not including the value of personal assets and property such as primary residences, collectibles, consumables, and consumer durables (WWR, 2013). As there is a large amount of millionaires around the world, ultra high-net worth individuals (UHNWI) appeared. Ultra-HNWI is defined as an individual with more than US\$30 million in financial assets (WWR, 2007). High-net worth individuals are also divided into three groups: lower band HNWIs (US\$1 million to US\$5 million), mid-tier HNWIs (US\$5 million to US\$20), and upper-tier HNWIs (over US\$20 million) (WWR, 2013). These millionaires, according to the above mentioned classification are also called "dollar millionaires", based on their assets on international stock markets.

According to Focus.de, 50 percent of dollar millionaires live in the top three millionaire destinations - the US, Japan, and Germany, with the world's fastest growing millionaire populations to be found in Hong Kong, India, Thailand, and New Zealand (Focus.de 2013, cited in The Local Germany's News in English, 2013).

In Figure 2, there is presented largest HWNI population growth by country in the years 2011 and 2012, from which it is seemed that the top five countries are the U.S., Japan, Germany, China, and the U.K. The United States has a definitive lead. Latvia, however, is not among these countries. 


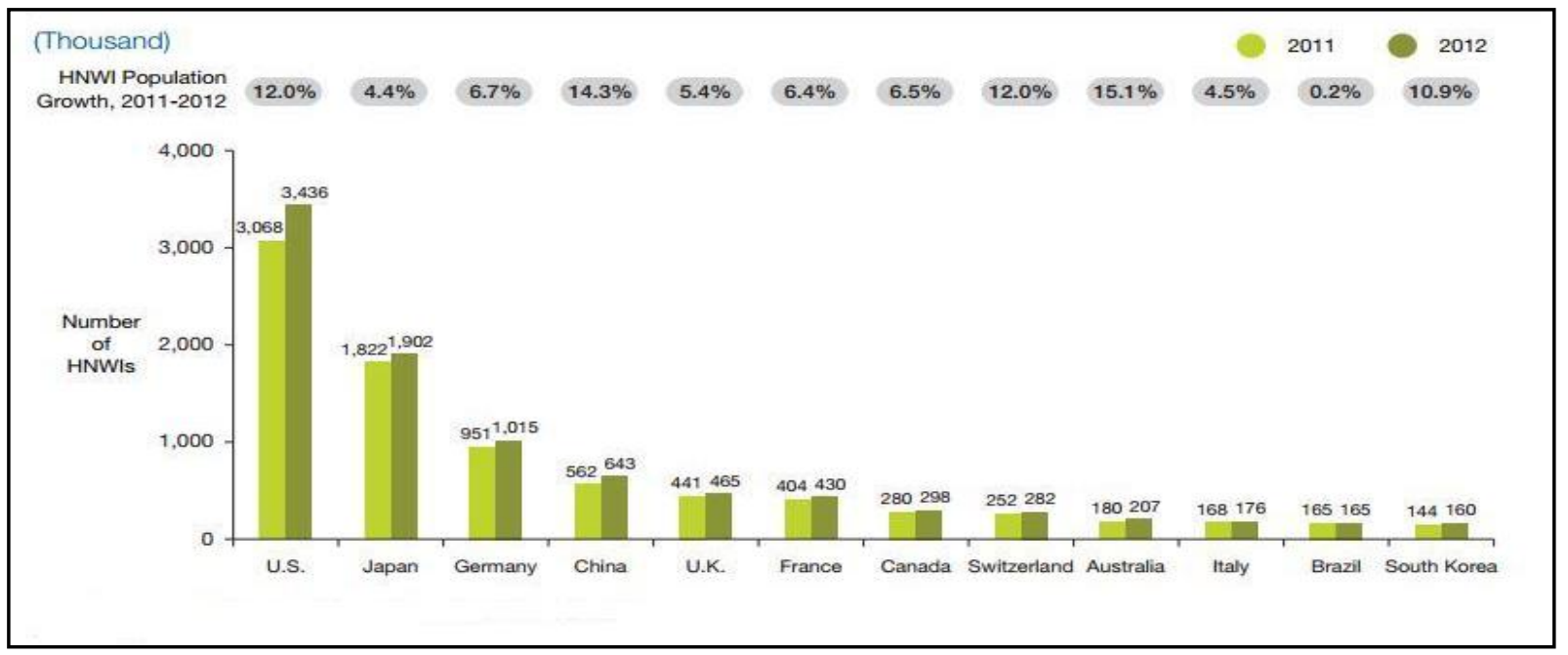

Figure 2. Largest HWNI populations, 2012 (by Country). Note: Percentage growth rates will not match column totals due to rounding. Source: Capgemini Lorenz Curve Analysis (2013).

\section{Successful Entrepreneurs in Latvia}

In Latvia, in December 2013, a respective business magazine "Kapitals" published a list of TOP 100 millionaires in the country. The list was created by Lato Lapsa, Kristine Jancevska, and "Baltic Screen" in cooperation with corporate finance companies "Laika stars" and "Lursoft".

The data shows that the wealthiest people are those working in the finance and pharmaceutical industries (owners of ABLV bank, Rietumu bank, Olainfarm, and Recipe plus pharmacy companies). The top three wealthiest businessmen in Latvia are operating in the financial services industry. Their assets have grown in comparison with the previous year.

\section{Conclusions}

Our first hypothesis is confirmed partially. Export is among the most significant critical success factors; however, it is not primary. Finding a specific niche is seen as more critical by the interviewed companies. Our second hypothesis has been disapproved, as government funding was mentioned only once as a supplementary CSF. The third hypothesis has also been rejected, as during the research, 30 critical-to-success factors were named in the interviews. The acquired information proves our fourth hypothesis, that both large and medium companies have specific business sectors with the highest turnover levels that coincide. The fifth hypothesis is proven - specific market niche, which was number one CSF according to Forbes magazine interviews, is only critical to small companies, such as SIA Brain Games, as this is their way to enter new markets and grow. Large companies (NP Foods, Cleanhouse) note that specific market niche is not critically important; as these enterprises do not operate in a narrow industry. Our sixth hypothesis is partially confirmed. The EU funds CSF is of great significance; however, only one company gave this factor 5 points out of 5 . Other companies gave it 3 points of 5 . Four companies out of six define this CSF as significant. The seventh hypothesis, which states that there are several CSF that both large and SME define as of great and vital importance, is confirmed. There are seven leading CSF: High quality product (6 out of 6 companies gave this CSF 5 points out of 5), learning organisation (4 out of 6), team work (4 out of 6), CRM (4 out of 6), export, market niche and technological innovations were stressed by 3 out of 6 companies. According to interviews in Forbes magazine, the most significant critical success factors are a specific market niche, export, technological innovations and high 
quality of products and services. CSF according to Forbes interviews coincide with the ones that are defined in the six in-depth interviews. Moreover, these personal interviews reveal three additional factors-learning organisation, team work and CRM, as well as stressing the importance of high quality of products factor.

It is additionally found that the 10 largest (and most profitable) industries for the big companies are: fuel retail and wholesale (approx. 3,605 bil. euro), energy (approx. 1,821 bil. euro), food retail and wholesale (approx. 1,689 bil. euro), chemical products (approx. 1,519 bil. euro), logistics (approx. 1,235 bil. euro), metal processing (approx. 1,019 bil. euro), financial services (approx. 896 mil. euro), information technologies service and production (approx. 857 mil. euro), passenger transportation (approx. 705 mil. euro) and telecommunication services (approx 539 mil. euro). For medium companies such industries are: food retail and wholesale (approx 1,365 bil. euro), logistics (approx. 842 mil. euro), fuel retail and wholesale (approx. 657 mil. euro), wood processing (approx. 521 mil. euro), automotive industry (approx. 466 mil. euro), construction (approx. 451 mil. euro), financial services (approx. 355 mil. euro), pharmaceutical products (approx. 276 mil. euro), metal processing (approx. 273 mil. euro), and beverage wholesale and production (approx. 252 mil. euro). The data also show that the wealthiest people are those working in the finance and pharmaceutical industries (owners of ABLV bank, Rietumu bank, Olainfarm and Recipe plus pharmacy companies). The top three wealthiest businessmen in Latvia are operating in financial services industry.

\section{Recommendations}

Taking into account the received data, the authors of the paper can come to a conclusion and provide recommendations that in Latvia, it is important to choose a specific market niche in which an enterprise will operate, especially if you are a small or medium business. Latvian companies that survived crisis in 2008, highlight in their interviews that it is important to perform business in a particular sphere. Potential investors should plan export activities three-four years upfront, as this CSF is also stressed as crucial. The most important and vitally important factor is to provide high quality services or produce high quality products to be a successful company in Latvia. Innovations, both in marketing and technological spheres, play a significant role in operating business in the above mentioned country. However, potential investors should not rely on government funding, as this factor is mentioned only once and as a supplementary CSF. Nevertheless, there is support available from EU funds, which is mainly used for participating in international exhibitions and for the purchase of equipment. Team work, maintaining good relations with clients and constant learning will also help in achieving success on the Latvian market.

Financial services and pharmaceutical industries are the most profitable spheres, both according to the analysis of the TOP 500 largest companies and the list of wealthiest people in Latvia. Therefore, the above mentioned industries are the ones that the authors of the paper recommend when starting a new business in Latvia. However, there may be a high level of competition, which must also be taken into account. The list of other profitable spheres is available in the conclusions part of the present paper.

\section{References}

Aizsilnieks, A. (1968). Latvijas saimniecibas vesture (The history of Latvian National Economy) (p. 983). Stockholm: Daugava. American Latvian Association. (1968). Latvia. American Latvian Association, Washington DC.

Berry, L. L., Seiders, K., \& Gresham, L. G. (1997). For love and money: The common traits of successful retailers. Managing Service Quality, 26(2), 7-23.

Brotherton, B. (2004). Critical success factors in UK budget hotel operations. International Journal of Operations \& Production 
Management, 24(9), 944-969.

Brotherton, B., \& Shaw, J. (1996). Towards an identification and classification of critical success factors in UK Hotels Plc. International Journal of Hospitality Management, 15(2), 113-135.

Business Dictionary. (2014). Export. Retrieved from http://www.businessdictionary.com/definition/export.html

Business Dictionary. (2014). Market niche. Retrieved from http://www.businessdictionary.com/definition/market-niche.html

Cambridge Business English Dictionary. (2011). Cambridge University Press, Cambridge.

Capon, N., \& Glazer, R. (1987). Marketing and technology: A strategic coalignment. Journal of Marketing, 51(7), 1-14.

Daniel, D. R. (1961). Management information crisis. Harvard Business Review, 39, 111-120.

Garvin, D. (1984). What does product quality really mean? Sloan Management Review, 26(1), 25-43.

Harris, A. (2007). How to marry a billionaire. Retrieved February 4, 2014, from http://money.cnn.com/magazines/moneymag/moneymag_archive/2007/07/01/100116670/

Howell, M. T. (2010). Critical success factors simplified: Implementing the powerful drivers of dramatic business improvement. New York: Productivity Press.

Investment and Development Agency of Latvia (LIAA). (2014). Sectors and industries. Retrieved February 4, 2014, from http://www.liaa.gov.lv/invest-latvia/sectors-and-industries

Johnson, G., \& Scholes, K. (1993). Exploring corporate strategy: Text and cases (3rd ed.). Hemel Hempstead: Prentice-Hall International (UK) Ltd.

Kapitals. (2013). Top 100 Latvian millionaires. Riga: SIA “Izdevnieciba IKK”.

Latvijas Banka. (2014). The history of the bank of Latvia. Retrieved April 21, 2014, from http://www.bank.lv/par-latvijas-banku/latvijas-bankas-vesture

Leonidou, L. C., Katsikeas, C. S., \& Coudounaris, D. N. (2010). Five decades of business research into exporting: A bibliographic analysis. Journal of International Management, 16(1), 78-91.

Martinsons, M. G., \& Valdemars, K. (1992). Post-Soviet Reform in Latvia: Early progress and future prospects. Journal of Economic Studies, 19(6), 33-52.

McPherson, M., \& Nunes, B. (2006). Critical success factors as identified by HE practitioners. International Journal of Educational Management, 20(7), 542-558.

Mohibul and Alejandra. (2008). Internalization process of SMEs: Strategies and methods (p. 11). Sweden: Master paper.

Oxford Business Dictionary (2006). Oxford University Press, USA.

Remus, U. (2007). Critical success factors for implementing enterprise portals: A comparison with ERP implementations. Business Process Management Journal, 13(4), 538-552.

Robson, W. (1994). Strategic management and information systems: An integrated approach. London: Pitman.

Rockart, J. F. (1979). Chief executives define their own data needs. Harvard Business Review, 57(2), 81-93.

Rockart, J. F. (1982). The changing role of the information systems executive: A critical success factors perspective. Sloan Management Review, 24(1), 3-13.

Rowlinson, S. (1999). Selection criteria. In S. Rowlinson, \& P. McDermott (Eds.), Procurement systems: A guide to best practice (pp. 276-299). London: E and F.N. Spon.

Strods, H. (1992). Latvijas lauksaimniecibas vesture (The history of Latvian agriculture) (p. 287). Zvaizgne.

The Local Germany's News in English. (2013). Germany home to one million millionaires. Retrieved February 4, 2014, from http://www.thelocal.de/20130619/50405

The Ministry of Finance. (2013). Money in action: What to expect? Retrieved June 13, 2014, from http://www.esfondi.lv/naudadarbiba/kas-gaidams/

The Ministry of Finance. (2014). EU funds managing authority. Retrieved June 13, 2014, from http://www.fm.gov.lv/en/s/es_un_arvalstu_finansu_palidziba/es_fondu_vadosa_iestade/

Tilde. (1998-2012). Tildes Datorenciklopedija Latvijas Vesture (Tilde computer encyclopaedia: The history of Latvia). Retrieved February 4, 2014, from http://www.letonika.lv/groups/default.aspx?g=1\&r=2

World Wealth Report (WWR) (2013). Capgemini. RBC Wealth Management, Wealth Report.

World Wealth Report (WWR). (2007). Capgemini. RBC Wealth Management, Wealth Report. 